\title{
Humoral antibody response of brown trout Salmo trutta vaccinated against furunculosis
}

\author{
Ann Thuvander ${ }^{1, *}$, U. P. Wichardt ${ }^{2}$, Liv Jorun Reitan ${ }^{3}$ \\ ${ }^{1}$ Department of Immunology, Uppsala University, Box 582, S-751 23 Uppsala, Sweden \\ ${ }^{2}$ Salmon Research Institute, S-810 70 Älvkarleby, Sweden \\ ${ }^{3}$ National Veterinary Institute, Box 8156 Dep, N-0033 Oslo, Norway
}

\begin{abstract}
Two year old brown trout Salmo trutta L. in a freshwater farm with a history of enzootic Aeromonas salmonicida infections were vaccinated with a commercial vaccine against furunculosis by intraperitoneal injection either with or without a booster. Antibody levels to 3 cellular antigen preparations from $A$. salmonicida, i.e. whole cells of $A$. salmonicida, A-layer protein, and lipopolysaccharide (LPS) isolated from the bacterium, were measured using an ELISA technique. Antibodies to whole cell A. salmonicida and LPS were demonstrated in both vaccinated and non-vaccinated fish. Antibodies to A-layer protein were only detected in very low quantities in non-vaccinated fish. In vaccinated fish, the levels of these antibodies were significantly higher in boosted fish than in fish vaccinated only once. Western blot analyses of fish serum also revealed antibodies to LPS and A-layer protein. Antibody activities to extracellular products from A. salmonicida were mainly against a $70 \mathrm{kDa}$ component and LPS. Prior to a challenge test in which furunculosis was induced by increasing the water temperature, all fish were bled and individually marked. Only boosted fish showed significant protection in this challenge, and no mortalities were recorded in this group. The groups of fish which had received only $1 \mathrm{immunization}$ were not protected against furunculosis. In these groups, pre-challenge antibody levels to cell membrane antigens, as measured by ELISA, did not differ between survivors and non-survivors. This indicates that high levels of specific antibodies to cellular antigens do not correlate with survival of the individual fish.
\end{abstract}

KEY WORDS: Furunculosis - Brown trout · Antibody response

\section{INTRODUCTION}

Vaccination of salmonid fish against furunculosis, a disease caused by the Gram-negative bacterium Aeromonas salmonicida, has given inconclusive results (reviewed by Hastings 1988). A certain degree of protection is often obtained after vaccination (Smith et al 1980, McCarthy et al. 1983, Newman \& Majnarich 1985 Erdal \& Reitan 1992, Lillehaug et al. 1992) but the immunological mechanisms of this protection remain unknown. Several authors have reported poor correlation between agglutinating antibodies to $A$. salmonicida and protective immunity (Cipriano 1982, 1983, Michel \& Faivre 1982, McCarthy et al. 1983, Olivier et al. 1985a), and it has been suggested that the observed protection

\footnotetext{
- Present address: National Food Administration, Box 222,
} S-751 26 Uppsala, Sweden is partly non-specific (Olivier et al. 1985b, Adams et al. 1988, Michel et al. 1990). However, studies of passive immunization of fish with immune sera from fish or rabbits have shown that humoral factors can protect fish against furunculosis (Spence \& Fryer 1965, Cipriano 1982, McCarthy et al. 1983, Olivier et al. 1985a, Ellis et al. 1988a, Marquis \& Lallier 1989). When the passive protection is obtained by injection of rabbit immune sera, these humoral factors seem to be specific antibodies to A. salmonicida (Marquis \& Lallier 1989).

A number of cellular and extracellular components of importance for the virulence of Aeromonas salmonicida have been described. Passive immunization studies have suggested 2 of these components to be protective: the A-layer protein (McCarthy et al. 1983) and an extracellular protease (Ellis et al. 1988a). So far, however, little effort has been made to analyze the antibody repertoire of fish which are protected against 
furunculosis. The aim of the present study was therefore to measure the antibody response to cellular and extracellular antigens from $A$. salmonicida in vaccinated brown trout and to compare antibody levels with protective immunity of the individual fish.

\section{MATERIALS AND METHODS}

Fish. Two year old brown trout Salmo trutta with an average weight of $60 \mathrm{~g}$ were used in the study. They were kept in 16 basins ( 8001 per basin), each containing 200 individuals. The fish had been transported from the hatchery to the Bonäshamn fish farm (Jämtland, Sweden) the previous autumn. On this farm furunculosis has been enzootic since 1951 (Wichardt et al. 1989). However, due to the low water temperatures during most of the year there are few clinical outbreaks of furunculosis.

Vaccination. The fish from 8 of the 16 basins were anaesthetized in buffered MS-222 (100 $\mathrm{mg} \mathrm{l}^{-1}$; Sandoz) and vaccinated intraperitoneally (ip) with $0.1 \mathrm{ml}$ of a commercial vaccine to furunculosis (Furogen; Aqua Health Ltd, Charlottetown, Canada). Water temperature at the time of vaccination (June) was $6.5^{\circ} \mathrm{C}$.

Four weeks after the vaccination, the fish in 4 of the basins were given booster injections as described above. Further, the fish in 4 of the basins containing non-vaccinated fish were on this occasion vaccinated ip as described above. Water temperature at this time was $8.9^{\circ} \mathrm{C}$.

Sampling and tagging. Caudal blood samples for antibody analyses were obtained from the anaesthetized fish in conjunction with the first vaccination, at $8 \mathrm{wk}$ after the first vaccination, and prior to the challenge test (13 wk after the first vaccination). Before the fish were transferred to the tanks for the challenge test, they were individually bled and tagged with Floy-tags.

Challenge test. Thirteen weeks after the first vaccination, 10 fish were randomly collected from each of the 16 basins and transferred to $40 \mathrm{l}$ challenge tanks ( 1 tank for each basin). The water temperature in the challenge tanks was gradually increased from the ambient temperature of approximately $12^{\circ} \mathrm{C}$ up to $18^{\circ} \mathrm{C}$, which induced acute mortality due to furunculosis. Mortalities were recorded, and dead fish were removed daily for $20 \mathrm{~d}$. Samples from the kidneys were cultured on tryptic soy agar from all fish in the challenge in order to isolate Aeromonas salmonicida. Mortalities were compared between groups with the Chi-square test.

Antibodies to Aeromonas salmonicida. Polyclonal antisera to $A$. salmonicida were obtained from rabbits vaccinated intravenously with $10^{8}$ whole and formalinkilled cells of $A$. salmonicida subsp. salmonicida (strain F.t. 337) 7 times at an interval of 4 d. The rabbits were bled and the sera were stored at $-20^{\circ} \mathrm{C}$.
To prepare monoclonal antibodies, Aeromonas salmonicida subsp. salmonicida (strain 3173/86) was grown in trypticase soy broth (TSB) for $24 \mathrm{~h}$ at $22^{\circ} \mathrm{C}$, inactivated with $0.5 \%$ formalin overnight, washed 3 times with sterile phosphate-buffered saline (PBS), and adjusted to $10^{9}$ bacterial cells $\mathrm{ml}^{-1}$. A volume of $0.1 \mathrm{ml}$ was injected ip into each of $2 \mathrm{BALB} / \mathrm{C}$ mice 3 times at 2 mo intervals. Four days after the last injection, cell suspensions were prepared from the spleens of the immunized mice. The lymphocytes were fused with the myeloma cell line NS-0 (Köhler \& Milstein 1975). One clone with activity to A-layer protein (84A) and one with activity to LPS (84B) were selected and subcloned by limiting dilution. The isotypes of the antibodies, IgG2a, were determined in an ELISA. The 2 clones were injected ip into Pristaneprimed BALB/C mice and ascitic fluid was collected. The specificity of the 2 antibodies was confirmed by immunoblot.

Antigens. The following antigen preparations were used in screening the fish serum for specific antibodies:

(1) Whole cell Aeromonas salmonicida subsp. salmonicida (strain 399/88) was cultured in TSB for $20 \mathrm{~h}$ at $25^{\circ} \mathrm{C}$. The cells were washed 3 times in PBS (pH 7.4), inactivated with $0.4 \%$ formalin overnight, and washed another 3 times. Finally, the concentration of the bacteria was adjusted with $0.05 \mathrm{M}$ carbonate buffer ( $\mathrm{pH}$ 9.6) to $\mathrm{OD}_{510}=0.6$.

(2) Lipopolysaccharide (LPS) from $A$. salmonicida subsp. salmonicida (399/88) was isolated as described by Westphal \& Jann (1965).

(3) A-layer protein from $A$. salmonicida subsp. salmonicida (strain $3173 / 86$ ) was isolated as described by Phipps et al. (1983).

(4) Extra-cellular products (ECPs) were prepared as described by Austin \& Rodgers (1981). Briefly, $A$. salmonicida subsp. salmonicida (strain 3173/86) were cultured on a sterile sheet of dialysis membrane (Ancos, Vig, Denmark) overlaid on plates of TSA. After $48 \mathrm{~h}$ at $22^{\circ} \mathrm{C}$ the cells were washed off the membrane with $3 \mathrm{ml}$ PBS. The suspension was centrifuged $(5000 \times g, 20 \mathrm{~min})$ and the supernatant (containing the ECP) was filtered $(0.22 \mu \mathrm{m})$ and stored at $-70^{\circ} \mathrm{C}$.

Western blots. Sodium dodecyl sulphate polyacrylamide gel electrophoresis (SDS-PAGE) was performed in $4 \%$ stacking gel and $12 \%$ separating gel according to the method described by Laemmli (1970). Samples of the various antigen preparations to be subjected to SDS-PAGE were prepared according to the method described by Hitchcock \& Brown (1983).

Molecular weight markers (Rainbow, Amersham, UK) were run for gels to be blotted and SDS Page Standard Low markers (Bio-Rad, Richmond, USA) were 
run for gels to be stained. Electrophoresis was performed at $27 \mathrm{~V} \mathrm{~cm}^{-1}$ for 50 min (Bio-Rad Protean R II Dual Slab Cell). The separated bands were either stained with $0.2 \%$ Coomassie brilliant blue or transferred electrophoretically at $300 \mathrm{~V}$ for $1 \mathrm{~h}$ and immobilized onto $0.45 \mu \mathrm{m}$ nitrocellulose sheets (Ancos, Vig, Denmark) in a semi-dry system as described by KyhseAndersen (1984). The sheets were washed twice in PBS and non-specific binding was blocked by incubation with $1 \%$ bovine serum albumin (BSA A-9647, Sigma) for $1 \mathrm{~h}$ at room temperature, followed by 3 washings in PBS with $0.5 \%$ Tween (PBS-T). Polyclonal rabbit antiserum to Aeromonas salmonicida (diluted 1:100), mouse monoclonal antibodies to $A$. salmonicida (ascites diluted 1:1000), or pooled serum samples from fish (diluted 1:20), all of which were diluted in PBS-T, were incubated overnight at $4{ }^{\circ} \mathrm{C}$. The filters that had been incubated with fish serum were then washed 3 times with PBS-T and incubated with a mouse monoclonal antibody to salmon IgM (clone 4c10 raised against rainbow trout IgM; Thuvander et al. 1990), contained in ascitic fluid diluted 1:200 for $2 \mathrm{~h}$ at room temperature. Following 3 washings in PBS-T, filters were incubated for $2 \mathrm{~h}$ at room temperature in peroxidase-labelled donkey anti-rabbit Ig or sheep antimouse IgG (Amersham), as appropriate. Filters were then washed 3 times in PBS-T, once in PBS, and rinsed once briefly in $0.05 \mathrm{M}$ sodium acetate, pH 5.0. Finally, the blots were developed in a substrate solution containing 3-amino 9-ethyl-carbazole (AEC, Sigma) in $0.05 \mathrm{M}$ sodium acetate, $\mathrm{pH} 5.0$ and $\mathrm{H}_{2} \mathrm{O}_{2}$. The reaction was stopped by rinsing the blots in tap water.

ELISA. Two hundred $\mu \mathrm{l}$ of the respective antigens diluted in $0.05 \mathrm{M}$ carbonate buffer, pH 9.6 (whole cell Aeromonas salmonicida diluted 1:100; LPS, $10 \mu \mathrm{g} \mathrm{ml}^{-1}$; A-layer protein, $2 \mu \mathrm{g} \mathrm{ml}^{-1}$ ) was coated onto polystyrene microtitre plates (Costar) and incubated at room temper- ature overnight. After washing the plates 3 times in $0.9 \%$ $\mathrm{NaCl}$ with $0.05 \%$ Tween, $100 \mu \mathrm{l}$ of fish serum, diluted 1:100 in PBS-T, was added and the plates were incubated at $4{ }^{\circ} \mathrm{C}$ overnight. After 3 more washings, $100 \mu \mathrm{l}$ well ${ }^{-1}$ of a mouse monoclonal antibody (clone $4 \mathrm{c} 10$ ) to salmonid IgM, ascitic fluid diluted 1:10 000 in PBS-T, was added to the plates. The plates were then incubated for $1.5 \mathrm{~h}$ at $37^{\circ} \mathrm{C}$ and washed. After this, $100 \mu \mathrm{l}$ well ${ }^{-1}$ of rabbit anti-mouse Ig conjugated to horseradish peroxidase (Dakopatt, Denmark), diluted 1:1000 in PBS-T, was added and the plates were incubated for $45 \mathrm{~min}$ at $37^{\circ} \mathrm{C}$. After washing, $200 \mu \mathrm{l}$ well $^{-1}$ of tetramethylbenzidine (Kebo, Stockholm, Sweden) at a concentration of $0.1 \mathrm{mg}$ $\mathrm{ml}^{-1}$ in $0.1 \mathrm{M}$ sodium acetate buffer ( $\mathrm{pH} 6.0$ ), containing $0.0025 \% \mathrm{H}_{2} \mathrm{O}_{2}$, was added. The reaction was stopped after $10 \mathrm{~min}$ with $50 \mu \mathrm{l} \mathrm{well}{ }^{-1}$ of $2 \mathrm{M} \mathrm{H}_{2} \mathrm{SO}_{4}$, and the optical density was read at $450 \mathrm{~nm}$. The mean absorbance values for duplicate wells were used to express humoral antibody levels. Antibody levels were compared for statistically significant differences using the 2 -tailed Student's $t$-test. Reference serum samples from immunized and control fish were included on each plate.

\section{RESULTS}

\section{Antibodies detected with Western blot}

The specificities of the 2 monoclonal antibodies produced, $84 \mathrm{~A}$ and $84 \mathrm{~B}$, were shown to be against the A-layer protein and the LPS of Aeromonas salmonicida, respectively. By using both a polyclonal anti- $A$. salmonicida antiserum and the monoclonal antibodies $84 \mathrm{~A}$ and $84 \mathrm{~B}$ in the Western blot technique, the ECP preparation used in this study was shown to contain considerable amounts of LPS, while the A-layer protein preparation contained only minor amounts of LPS (Fig. 1).

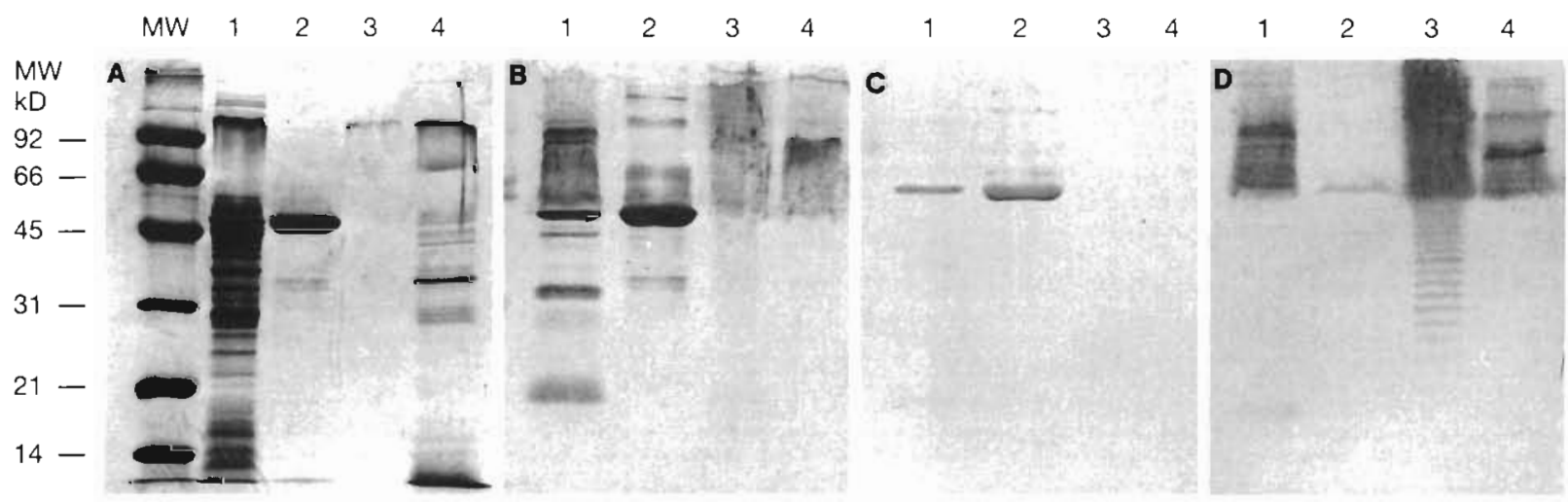

Fig. 1. PAGE and Western blots of separated antigens from Aeromonas salmonicida: (A) stained with Coomassie brilliant blue (B) developed by a polyclonal rabbit antiserum to $A$. salmonicida, (C) developed by a monoclonal antibody to A-layer protein (84A), and (D) developed by a monoclonal antibody to LPS (84B). Antigens are as follows: Lane 1, whole cell A. salmonicida Lane 2, A-layer protein; Lane 3, LPS; Lane 4, extracellular products 
Western blot analysis of pooled sera collected at 13 wk after the first vaccination revealed antibody activities to A-layer protein and LPS in all samples from immunized (boosted) fish, and in many of the sera from non-immunized fish. Further, antibody activity was detected to a $70 \mathrm{kDa}$ component of the ECP preparation, which was also recognized by the monoclonal antibodies to LPS (Fig. 1D) and by a polyclonal rabbit antibody against protease from Aeromonas salmonicida (data not shown). In a few non-vaccinated and vaccinated fish, a weak antibody activity to a component of the ECP preparation with a molecular weight of about $30 \mathrm{kDa}$ could be seen. The antibody activities against LPS, the $70 \mathrm{kDa}$ ECP component, and in particular against the A-layer protein in sera from boosted fish were clearly stronger than in non-vaccinated fish (Fig 2).

Antibodies detected by ELISA. Antibody levels to whole cell Aeromonas salmonicida, LPS, and A-layer protein at Weeks 0,8 , and 13 after the first vaccination were measured with ELISA (Fig. 3). All groups of fish showed rather high levels of antibodies to whole cell A. salmonicida and LPS even before they were vaccinated. Antibodies to A-layer protein, on the other hand, were only detected in very low quantities in non-vaccinated fish. Before the challenge test at 13 wk after the first vaccination, the level of antibodies to A-layer protein was significantly higher $(\mathrm{p}<0.001)$ in the boosted group than in the primed groups.

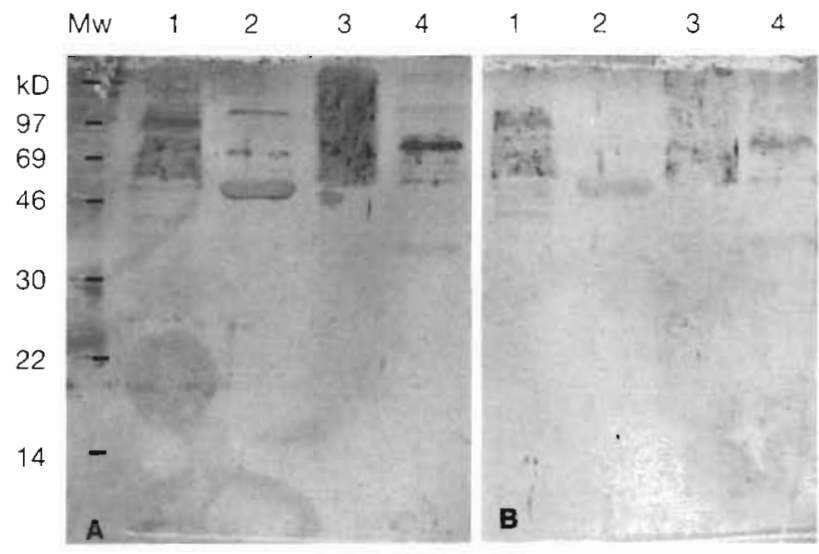

Fig. 2. Western blot of Aeromonas salmonicida antigens stained with fish sera (diluted 1:20): (A) a serum pool from 4 boosted brown trout Salmo trutta, and (B) a serum pool from 4 non-vaccinated brown trout. Antigens are as follows: Lane 1, whole cell A. Salmonicida lane 2, A-ldyer protein; Lane 3, LPS; Lane 4, extracellular products

\section{Mortality and antibody titres of fish in the challenge test}

Mortality induced by increasing the water temperature 13 wk after the first vaccination is shown in Table 1. Mortalities were most frequent in the nonvaccinated fish, but only boosted fish showed significant protection. Aeromonas salmonicida was isolated from the kidney in $71 \%$ of the dead fish in the test. Further, A. salmonicida could be detected in kidney cultures from a small number $(6 \%)$ of the surviving
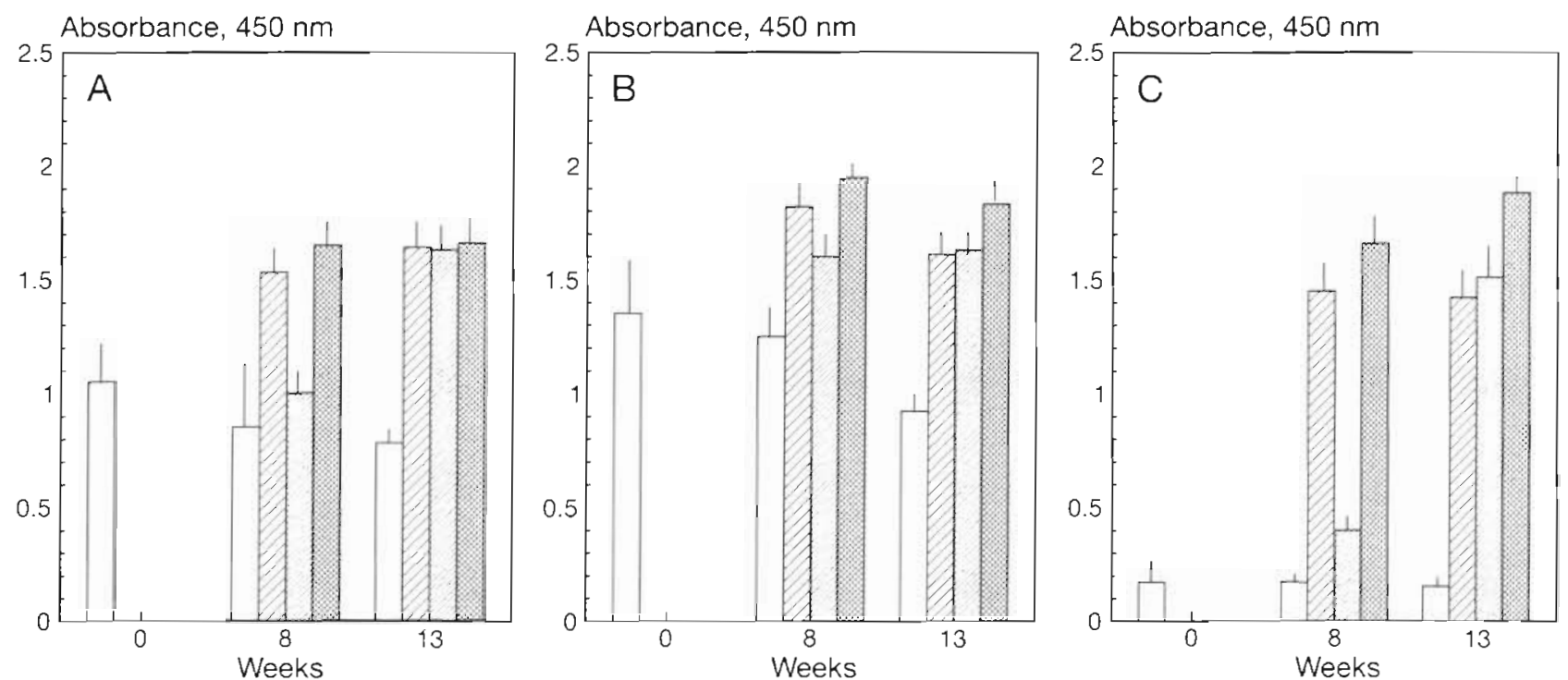

Fig. 3. Antibody levels measured with ELISA in serum from brown trout Salmo trutta vaccinated with a commercial vaccine against furunculosis. Antigens are: (A) whole cell Aeromonas salmonicida, (B) LPS from A. salmonicida, and (C) A-layer protein from $A$. sälmonicida. $\square$ Control fish, $\square$ fish vaccinated at Week $0, \square$ fish vaccinated at Week 4 , 0 fish vaccinated at Weeks 0 and 4. Data are given as mean +1 standard deviation for 13 fish (Week 0), 20 fish (Week 8), or 40 fish (Week 13) 
Table 1. Salmo trutta infected by Aeromonas salmonicida. Mortality following challenge of brown trout variously vaccinated against furunculosis

\begin{tabular}{|lrrrrr}
\hline Fish group & \multicolumn{4}{c|}{ Mortality in challenge } \\
& No. of fish per replicate tank & Total \\
\hline Control & $6 / 10$ & $2 / 10$ & $2 / 10$ & $2 / 10$ & $12 / 40$ \\
Vaccinated at Week 0 & $2 / 10$ & $0 / 10$ & $1 / 10$ & $4 / 10$ & $7 / 40$ \\
Vaccinated at Week 4 & $4 / 10$ & $2 / 10$ & $0 / 10$ & $0 / 10$ & $6 / 40$ \\
Vaccinated at Weeks 0 and 4 & $0 / 10$ & $0 / 10$ & $0 / 10$ & $0 / 10$ & $0 / 40^{b}$ \\
& & & \\
a Cumulative mortality in challenge 13 wk after the first vaccination \\
b Significantly lower mortality than that in the control fish $(p<0.001)$ or \\
in fish vaccinated at Week O (p<0.05) or at Week $4(p<0.05)$
\end{tabular}

poor correlation between protective immunity and agglutinating antibodies to A. salmonicida (Michel \& Faivre 1982, McCarthy et al. 1983, Olivier et al. 1985a).

Antibodies to A-layer protein were only detected in very low quantities in nonvaccinated fish. If the antibodies to LPS and whole cell Aeromonas salmonicida which were detected in non-vaccinated fish were induced by $A$. salmonicida present in the environment, this bacterial exposure only induced a weak antibody response to the A-layer protein. Alternatively, antibodies to A-layer protein

fish. All isolates were classified as A. salmonicida subsp. salmonicida.

Pre-challenge antibody levels were measured by ELISA in individual samples collected from the fish $13 \mathrm{wk}$ after the first vaccination. No differences in prechallenge antibody levels to any of the antigens were observed between surviving fish and fish that died during the challenge (data not shown).

\section{DISCUSSION}

The present results confirm that brown trout, like other saimonid species, can be partially protected against furunculosis by ip vaccination with an antigen preparation from Aeromonas salmonicida (Udey \& Fryer 1978, McCarthy et al. 1983, Olivier et al. 1985a, Paterson et al. 1985, Adams et al. 1988, Erdal \& Reitan 1992). In this study only boosted fish showed significant protection, which indicates that when using a vaccine consisting of formalin-inactivated $A$. salmonicida with aluminium phosphate as the only adjuvant, the level of protection increases with repeated vaccinations. The group of boosted fish also showed a significantly stronger antibody response to the A-layer protein, as measured by ELISA, than did fish which were only vaccinated once.

Antibodies to LPS and whole cell Aeromonas salmonicida were detected in the fish prior to immunization. Antibody analyses of the fish in this farm performed in previous seasons have also revealed such antibodies, although at lower levels (data not shown). These antibodies, which are presumably induced by A. salmonicida or by cross-reacting bacteria present in the environment, were not responsible for the observed protection in this study. Antibodies to LPS and whole cell A. salmonicida were present in similar amounts in both primed and boosted fish, and the prechallenge levels of these antibodies did not differ between survivors and non-survivors in the challenge. These observations agree with previous reports on the may have been produced, but their persistence in the fish was shorter than that of the LPS and A. salmonicida antibodies. Before the challenge, the mean level of anti-A-layer-protein antibodies was significantly higher in the boosted group than in the primed groups, thus showing a positive correlation with protective immunity. McCarthy et al. (1983) have previously suggested that immunity to A-layer protein is linked to protection. They found that fish vaccinated with a bacterin which was supposed to contain the A-layer protein induced protection, while bacterins without Alayer protein were not effective in inducing protective immunity. Similarly, Olivier et al. (1985a) and Marquis \& Lallier (1989) concluded that passive transfer of immunity was dependent on antibodies to A-layer protein in the immune sera. In the present study, however, the levels of pre-challenge anti-A-layer-protein antibodies in the fish were similar in individuals that died as a result of the challenge and in individuals that survived the challenge. This indicates that although the levels of anti-A-layer-protein antibodies were higher in the group which was protected against furunculosis than in the groups with no protection, fish with high titres of anti-A-layer-protein antibodies were not always protected. Clearly, additional immune mechanisms may be involved in protection and this may include induction of immune responses to cellular antigens other than A-layer protein and LPS. Antigens which are important for survival and growth of $A$. salmonicida, and which may induce protection against furunculosis, are the iron-regulated membrane proteins (IRMPs; Hirst et al. 1991). The protective value of an antibody response to these iron-uptake $A$. salmonicida proteins remains, however, to be evaluated.

Pathological lesions of typical furunculosis can be caused by extracellular products from Aeromonas salmonicida (Ellis et al. 1981), and it has been suggested that induction of immunity to ECPs is of prime importance in protecting fish against furunculosis. The main component of the ECP responsible for pathogenic and lethal effects is identified as a complex of the enzyme 
glycerophospholipid:cholesterol acyltransferase and lipopolysaccharide (GCAT/LPS) (Lee \& Ellis 1990). The GCAT/LPS complex, in combination with a $70 \mathrm{kDa}$ protease which is another important factor of the ECP, induces the same furuncle formation when injected into fish as does the ECP (Lee \& Ellis 1991). In a study on passive immunization of rainbow trout with rabbit antisera to A. salmonicida, Ellis et al. (1988a) identified the extracellular protease as a protective antigen. However, it has been reported that ECPs are poorly immunogenic in salmonid fish (Ellis et al. 1988b, Hastings \& Ellis 1988, Lund et al. 1991). In the present study, strong antibody activities to a $70 \mathrm{kDa} A$. salmonicida component were detected by the Western blot technique in sera from boosted fish. Although this $70 \mathrm{kDa}$ component was recognized by a polyclonal rabbit anti-protease serum, it was also recognized by monoclonal antibodies to A. salmonicida LPS (Fig. 1D). It is thus possible that the antibody activity detected in sera from boosted fish was partly directed against the protease. To evaluate the protective role of an antibody response to this protease, studies will have to be conducted with fish vaccinated with the purified protease.

Acknowledgements. This study was supported by grants from the Swedish Council for Forestry and Agricultural Research. The authors thank Rolf Hedgren for technical assistance, and Dr Otto Closs for his assistance in preparing the monoclonal antibodies. We also thank Bonäshamn fish farm and Water Regulation Enterprises, Östersund, for their help and for providing us with working facilities. Drs R. Gudding and A. Lillehaug are gratefully acknowledged for their support and for constructive criticism of the manuscript.

\section{LITERATURE CITED}

Adams, A., Auchinachie, N., Bundy, A., Tatner, M. F., Horne, M. T. (1988). The potency of adjuvanted injected vaccines in rainbow trout (Salmo gairdneri Richardson) and bath vaccines in Atlantic salmon (Salmo salar L.) against furunculosis. Aquaculture 69: 15-26

Austin, B., Rodgers, C. J (1981). Preliminary observations on Aeromonas salmonicida vaccines. In: Anderson, D. P., Hennessen, W. (eds.) Proceedings of the International Symposium on Fish Biologics, Serodiagnostics and Vaccines, Vol. 49, Developments in biological standardization. S. Karger, Basel, p. 387-393

Chart, H., Trust, T J. (1983). Acquisition of iron by Aeromonas salmonicida. J. Bacteriol. 156: 758-764

Cipriano, R. C. (1982). Immunization of brook trout (Salvelinus fontinalis) against Aeromonas salmonicida: immunogenicity of virulent and avirulent isolates and protective ability of different antigens. Can. J. Fish. Aquat. Sci. 39: $218-221$

Cipriano, R. C. (1983). Resistance of salmonids to Aeromonas salmonicida: relation between agglutinins and neutralizing activities. Trans. Am. Fish. Soc. 112: 95-99

Davies, R. L. (1991). Yersinia ruckeri produces four ironregulated outer membrane proteins but does not produce detectable siderophores. J. Fish Dis. 14: 563-570
Ellis, A. E., Burrows, A. S., Hastings, T S., Stapleton, K. J. (1988a). Identification of Aeromonas salmonicida extracellular protease as a protective antigen against furunculosis by passive immunization. Aquaculture 70 : $207-218$

Ellis, A. E., Hastings, T S., Munro, A. L. S. (1981). The role of Aeromonas salmonicida extracellular products in the pathology of furunculosis. J. Fish Dis. 4: 41-51

Ellis, A. E., Stapleton, K. J., Hastings, T S. (1988b). The humoral immune response of rainbow trout (Salmo gairdnen) immunised by various regimes and preparations of Aeromonas salmonicida antigens. Vet. Immunol. Immunopathol. 19: 153-164

Erdal, J. I., Reitan, L. J. (1992). Immune response and protective immunity after vaccination of Atlantic salmon (Salmo salar L.) against furunculosis. Fish Shellfish Immunol. 2: 99-108

Hastings, T. S. (1988). Furunculosis vaccination. In: Ellis, A. E. (ed.) Fish vaccination. Academic Press, London, p. $93-111$

Hastings, T S., Ellis, A. E. (1988). The humoral immune response of rainbow trout, Salmo gairdneri Richardson, and rabbits to Aeromonás salmonicida extracellulâr products. J. Fish Dis. 11: 147-160

Hirst, I. D., Hastings, T. S., Ellis, A. E. (1991). Siderophore production by Aeromonas salmonicida. J. gen. Microbiol. 137: $1185-1192$

Hitchcock, P. J., Brown, T M. (1983). Morphological heterogeneity among Salmonella lipopolysaccharide chemotypes in silver-stained polyacrylamide gels. J. Bacteriol. 154: $269-277$

Kyhse-Andersen, J. (1984). Electroblotting of multiple gels: a simple apparatus without buffer tank for rapid transfer of proteins from polyacrylamide to nitrocellulose. J. biochem. biophys. Meth. 10: 203-209

Köhler, G., Milstein, C. (1975). Continuous cultures of fused cells secreting antibody of predefined specificity. Nature 256: $495-497$

Laemmli, U. K. (1970). Cleavage of structural proteins during assembly of the head of bacteriophage T4. Nature 227 : $680-685$

Lee, K.-K., Ellis, A. E. (1990). Glycerophospholipid:cholesterol acyltransferase complexed with lipopolysacharide (LPS) is a major lethal exotoxin and cytolysin of Aeromonas salmonicida: LPS stabilizes and enhances toxicity of the enzyme. J. Bacteriol. 172: 5382-5393

Lee, K.-K., Ellis, A. E. (1991). The role of the lethal extracellular cytolysin of Aeromonas salmonicida in the pathology of furunculosis. J. Fish Dis. 14: 453-460

Lillehaug, A., Lunder, T., Poppe, T T (1992). Field testing of adjuvanted furunculosis vaccines in Atlantic salmon, Salmo salar L. J. Fish Dis. 15: 485-496

Lund, V., Jörgensen, T., Holm, K. O., Eggset, G. (1991). Humoral immune response in Atlantic salmon. Salmo salar L., to cellular and extracellular antigens of Aeromonas salmonicida. J. Fish Dis. 14: 443-452

Marquis, H., Lallier, R. (1989). Efficacy studies of passive immunization against Aeromonas salmonicida infection in brook trout, Salvelinus fontinalis (Mitchell). J. Fish Dis. 12: $233-240$

Mazoy, R., Lemos, M. L. (1991). Iron-binding proteins and heme compounds as iron sources for Vibrio anguillarum. Curr. Microbiol. 23: 221-226

McCarthy, D. H., Amend, D. F., Johnson, K. A., Bloom, J. V. (1983). Aeromonas salmonicida: determination of an antigen associated with protective immunity and evaluation of an experimental bacterin. J. Fish Dis. 6: 155-174 
Michel, C., Faivre, B. (1982). Occurrence and significance of agglutinating antibodies in experimental furunculosis of rainbow trout, Salmo gairdneri Richardson. J. Fish Dis. 5: $429-432$

Michel, C., Gonzales, R., Bonjour, E., Avrameas, S. (1990). A concurrent increasing of natural antibodies and enhancement of resistance to furunculosis in rainbow trout. Annls Rech. vét. 21: 211-218

Newman, S. G., Majnarich, J. J. (1985). Immunization of salmonids against furunculosis. Fish Pathol. 20: 403-411

Olivier, G., Evelyn, T P. T., Lallier, R. (1985a). Immunogenicity of vaccines from a virulent and an avirulent strain of Aeromonas salmonicida. J. Fish Dis. 8; 43-55

Olivier, G., Evelyn, T. P. T., Lallier, R. (1985b). Immunity to Aeromonas salmonicida in coho salmon (Oncorhynchus kisutch) induced by modified Freund's complete adjuvant: its non-specific nature and the probable role of macrophages in the phenomenon. Dev. comp. Immunol. 9: $419-432$

Paterson, W. D., Lall, S. P., Airdrie, D., Greer, P., Greenham, G., Poy, M. (1985). Prevention of disease in salmonids by vaccination and dietary modification. Fish Pathol. 20: $427-434$

Phipps, B. M., Trust, T. J., Ishiguro, E. E., Kay, W. W. (1983). Purification and characterization of the cell surface viru-

Responsible Subject Editor: T. Evelyn, Nanaimo, B.C., Canada lent A protein from Aeromonas salmonicida. Biochemistry 22: $2934-2939$

Smith, P. D., McCarthy, D. H., Paterson, W. D. (1980). Further studies on furunculosis vaccination. In: Ahne, W. (ed.) Fish diseases. Third COPRAQ session. Springer-Verlag, Berlin, p. $113-118$

Spence, K. D., Fryer, J. L. (1965). Active and passive immunization of certain salmonid fishes against Aeromonas salmonicida. Can. J. Microbiol. 11.397-405

Thuvander, A., Fossum, C., Lorenzen, N. (1990). Monoclonal antibodies to salmonid immunoglobulins: characterization and applicability in immunoassays. Dev. comp. Immunol. 14: $415-423$

Udey, L. R., Fryer, J. L. (1978). Immunization of fish with bacterins of Aeromonas salmonicida. Mar. Fish. Rev. 40: $12-17$

Westphal, O., Jann, K. (1965). Bacterial lipopolysaccharides. Extraction with phenol-water and further applications of the procedure. In: Whistler, R. N., BeMiller, J. N., Wolfrom, M. L. (eds.) Methods in carbohydrate chemistry. Academic Press, New York, p. 83-91

Wichardt, U. P., Johansson, N., Ljungberg, O. (1989). Occurrence and distribution of Aeromonas salmonicida infections on Swedish fish farms, 1951-1987. J. Aquat. Anim. Health 1. 187-196

Manuscript first received: July 27, 1992

Revised version accepted: July 13, 1993 